\title{
Xəstəlik tarixinin icmalı. \\ Petexiyalar, oliquriya və huşun keyləşməsi ilə daxil olmuş 21 yaşlı xəstə.
}

\author{
Nabil Seyidov, MD ${ }^{1}, \mathrm{PhD}$, Hafiz Həsənov, MD ${ }^{1}$, Vagif Nəbiyev, MD ${ }^{1}$, Denis Şabanov, MD ${ }^{1}$ \\ ${ }^{1}$ MediClub Hospital, Bakı, Azərbaycan Respublikası
}

\begin{abstract}
Abstrakt.
Burada trombotik trombositopenik purpura-hemolitik uremik sindromun kliniki mənzərəsi ilə daxil olmuş 21 yaşlı xəstənin xəstəlik tarixçəsini təqdim edirik. Xəstədə ümumi sağlamlıq fonunda aşağıdakı simptomlar və əlamətlər inkişaf etmişdir: orta dərəcəli trombositopeniya, mikroangiopatik hemolitik anemiya, keyləşmə və dizoriyentasiya; oligurik kəskin böyrək çatışmazlığı. Həmin simptomlar və əlamətləri izah edən digər etioloji səbəb aşkar edilməmişdir. Plazma mübadiləsi və təxminən üç həftə qlyukokortikoidlərlə aparılan müalicə nəticəsində xəstənin sağlamlığı tam bərpa edilmişdir.

Hər hansı aşkar səbəb olmadan trombositopeniya və mikroangiopatik hemolitik anemiyanın hazırkı diaqnostik meyarları TTP-i HUS-dan ayırmağa imkan vermir. Qeyd edilir ki, TTP olan xəstələrdə əsasən nevroloji pozuntular müşahidə edildiyi halda, HUS olan xəstələrdə əsasən böyrək çatışmazlığı müəyyən edilir. Lakin, bir çox hallarda xəstələrdə yanaşı olaraq həm nevroloji pozuntular, həm də böyrək pozuntuları və ya ümumiyyətlə nə nevroloji, nə də böyrək pozuntuları müşahidə edilə bilər. Buna görə də, yaşlılarda TTPnin HUS-dan fərqləndirilməsi çətindir.

HUS termini daha çox Şiqatoksin ifraz edən enterohemorragik E.Coli səbəbindən inkişaf etmiş trombositopeniya, mikroangiopatik hemolitik anemiya və kəskin böyrək çatışmazlığı olan az yaşlı uşaqlarda rast gəlinən xəstəliyin təsvirində istifadə edilir. Bu uşaqlar çox vaxt yalnız dəstəkləyici qayğı sayəsində yaxşılaşır və onların müalicəsində plazmaferez (plazma mübadiləsi) tələb olunmur. Lakin, bu sindrom diaqnozu qoyulmuş yaşlı xəstələrin müalicəsi plazma mübadiləsi ilə aparılır. Belə ki, plazma mübadiləsi aparılmadan yaşılıar arasında mortalite çox yüksək olur (>90\%). Plazma mübadiləsinin tətbiqi ilə böyrək çatışmazlığı və ya böyrək çatışmazlığı olmadan inkişaf etmiş HUS-TTP hallarında mortalite $20 \%$-dək azalmışdır.
\end{abstract}

Açar sözlər: trombotik trombositopenik purpura, hemolitik uremik sindrom, TTP-HUS, ADAMTS13, plazma mübadiləsi, plazmaferez, hemodializ, vWF-CP, petexiya, ekximoz, mikroangiopatik

\footnotetext{
Maliyyə mənbəyi: Məqalənin hazırlanması üçün digər qurumlardan və ya şəxslərdən əlavə maliyyə vəsaiti cəlb edilməmişdir. Maraqların toqquşması: qeyd edilmir.
} 


\section{GíRiş.}

TTP-HUS çoxsistemli patologiyadır və trombositlərin arteriyal damarlarda aqreqasiyası (aqqlyutinasiya) nəticəsində inkişaf edən trombositopeniya, mikroangiopatik hemolitik anemiya və işemik əlamətlərlə xarakterizə olunur. Plazma mübadiləsinin tətbiqindən əvvəl TTP hallarında mortalite $90 \%$-dan yüksək olub. Plazma mübadiləsinin tətbiqi ilə TTP və HUS halları ilə bağlı kliniki nəticələr xeyli yaxşılaşmışdır və buna görə də, TTP-HUS diaqnozu qoyulduqda plazma mübadiləsi təcili olaraq başlanmalıdır. Son dövrün araşdırmaları göstərmişdir ki, von-Willebrand faktorunun fizioloji parçalanmasında mühüm rola malik olan spesifik plazma proteazasının çatışmazlığı irsi və kəskin idiopatik TTP hallarının əksəriyyətinin inkişafında patogenik rola malikdir.

TPT-HUS hallarının inkişafında infeksiya, dərmanlar, xərçəng, kimya terapiyası, sümük iliyinin transplantasiyası və hamiləliyin triqqer rolu müəyyən edilsə də, həmin triqqerlərin TTP və HUS-un patogenezində oynadığı rol sonadək aydın deyildir. Geniş yayılmış olmasa da, ani başlanğıc, fulminant kliniki gedişatı və erkən diaqnostika və müalicə başlamadıqda yüksək morbidlik və mortalite ilə əlaqəli olduğu üçün, TTP və HUS xüsusi kliniki əhəmiyyətə malikdir.

$\mathrm{Bu}$ yaxınlaradək TTP və HUS sindromlarının təsnifatı əsasən kliniki əlamətlərə görə aparılırdı. Klinikada nevroloji disfunksiyası daha qabarıq olan xəstələrdə TTP, böyrək disfunksiyası daha qabarıq olan xəstələrdə isə HUS-un olduğu qeyd edilir. Lakin, bu iki sindromlar arasında müxtəlif simptom və əlamətlər çox vaxt üst-üstə düşür və onların dəqiq fərqləndirilməsi çox mübahisəli məsələdir.

\section{EPIDEMIOLOGIYA Və ӘНӘMIYYӘTі}

TTP və HUS az yayılmış olsa da, bu sindromların yüksək morbidlik və mortalite ilə bağlı olduğundan onlara erkən diaqnoz qoyulması və müalicəsinə başlanması xüsusi kliniki əhəmiyyət kəsb edir. Bir sıra qərb ölkələrində TTP, məsələn, hər bir milyon adam 3.7 hal düşür və son illərdə TTP və HUS hallarının sayı əksər ölkələrdə artmaqdadır. Bu artımın səbəbi, güman $\mathrm{ki}$, hər iki sindroma dair həkimlər arasında məlumatlıı̆̆ın yüksəlməsi, HiV infeksiyası hallarının artması, göstərişlərin genişləndirilməsi sayəsində sümük iliyi transplantasiyası hallarının çoxalması, habelə TTP/HUS-a səbəb olan dərmanların sayının artması ilə bağlıdır. 1970-ci illərdə empirik plazma mübadiləsinə əsaslanan terapiyanın tətbiqinədək TTP $90 \%$ mortalite ilə müşaiyət olunurdu. Hazırda isə plazma mübadiləsi (plazmferez) sayəsində kliniki nəticələr əhəmiyyətli dərəcədə yaxşılaşmış, lakin mortalite hələ də nisbətən yüksək olaraq (10-20\%) qalır. Ölüm hallarının böyük əksəriyyəti ilk 48 saat ərzində baş verir. Buna görə də TTP və HUS hallarının daha erkən müəyyən edilməsi və müalicəyə başlanılması çox əhəmiyyətlidir.

\section{PATOGENEZ.}

Həm TTP, həm də HUS-un damarlarda trombositlərin aqreqasiyası və/və ya endotel zədələnmə nəticəsində baş verdiyi ehtimal edilir. Damarlarda trombositlərdən ibarət mikrotrombların yaranması nəticəsində tükənmə trombositopeniyası, hədəf orqanların işemiyası və hissəvi obstruksiyaya məruz qalmış arteriollar və kapilyarlardan keçdikdə qırmızı qan hüceyrələrinin parçalanması səbəbindən damardaxili hemoliz müşahidə edilir. Damar daxilində formalaşaraq obstruksiyaya səbəb olan hiyalin trombları əsasən vWF, trombositlərdən və az miqdarda fibrin və ya fibrinogendən ibarət olur. Maraqlıdır ki, bir sıra araşdırmalarda TTP diaqnozu qoyulmuş xəstələrin plazmasında vWFnun böyük multimer formaları aşkar edilmişdir. Xatırladaq ki, vWF-nun bu cür böyük multimer formaları damarların endotel hüceyrələri və trombositlərdə mövcud olur, lakin plazmada normada təyin edilmir. vWV-nun bu cür yüksək yapışqanlığa (adhezivliyə) malik olan formalarının trombositlərin patoloji aqreqasiyasına (aqlyutinasiyası) səbəb olduğu guman edilir. TTPnin kəskin epizodu inkişaf etdikcə vWF-nun bu formaları plazmadan yox olur. $\mathrm{Bu}$ isə həmin formaların arteriolalar və kapilyarlarda mikrotrombların formalaşmasında iştirakı ilə bağlıdır. Qeyd edilməlidir ki, residivləşən TTP hallarında vWF-nun böyük multimer formaları yenidən plazmda təyin edilir. Maraqlıdır ki, remissiya zamanı plazmada vWF-nun böyük multimer formalarına yenidən rast gəlinməsi baş verəcək residivdən xəbər verir.

İki müxtəlif araşdırmada göstərilmişdir ki, vWF-nun böyük multimer formaları normada xüsusi plazma proteazası ( $\mathrm{VWF}$ cleaving protease VWF-CP və ya ADAMTS13 - a Disintegrin-like and Metalloproteaze with Thrombo-Spondin-1) tərəfindən normal ölçüyədək parçalanır. Araşdırmalar həm də göstərib ki, vWF-CP plazma proteazasının olmaması və ya aktivliyinin azalması vWF-nun böyük multimer formalarının tam parçalanmasını təmin etmir. Bu mexanizm TTP hallarının əksəriyyətində əsas patogenetik rola malikdir. Kəskin idiopatik TTP hallarının əksəriyyətində xəstələrin qanında vWFCP plazma proteazasına qarşı xüsusi autoanticimslər müəyyən edilir. Remissiya zamanı isə əksər xəstələrdə həmin auto-anticismlər yox olur və VWF-CP aktivliyi normaya qayıtmış olur. 
Endotelial zədələnmə TTP və HUS-un inkişafında digər etioloji faktor hesab edilir. Kimya terapiyası alan və ya sümük iliyi transplantasiyası almış xəstələrdə inkişaf edən TTP-HUS hallarında vWF$\mathrm{CP}$ çatışmazlığının olduğu təyin edilməmişdir. Buna görə düşünülür ki, kimya terapiyası və sümük iliyi transplantasiyası zamanı istifadə edilən sitotoksik preparatlar və ya digər immun mexanizmlər endotelial zədələnməyə səbəb olan əsas patogenetik mexanizmdir. Səbəbindən asılı olmayaraq, endotelial zədə nəticəsində plazmya vWF-nun böyük multimer formalarının ifrazı baş verir. Hətta vWF-CP plazma proteazasının aktivliyi normal olan xəstələrdə, endotelial zədə nəticəsində plazmaya birdən birə çoxlu həcmdə vWF-nun böyük multimer formaları düşdükdə plazmada olan vWF$\mathrm{CP}$ proteazası onları parçalamaq imkanında olmur. $\mathrm{Bu}$ cür vəziyyəti vWF-CP plazma proteazasının nisbi çatışmazlığı adlanır.

\section{XəSTOLIK TARIXININ MÜZAKIRəSI.}

\section{Osas şıkayət: huşun itməsi}

Anamnesis morbi. 21 yaşlı qadın xəstə tam sağlamlıq fonunda 16 radələrində baş ağrısı meydana çıxmış və tempalgin qəbulundan sonra rinit əlamətləri inkişaf etdiyi üçün klaritin içmişdir, daha sonra isə ürəkbulanma, qusma, qarında ağrı və ishal meydana çıxmışdır.Təkrari qusma(kofe tortasız və təzə qan izləri olmadan) 8-10 dəfə, və təkrari ishal 10-12 dəfə axşamdan gecəyə qədər davam etmiş və sonda xəstə huşunu itirmiş, üzündə qırmızı rəngli səthi ləkələr peyda olmuş və sürətlə üzündə yayılmağa başlamışdır və bundan sonra TYB çağrılmış və ilkin tibbi yardımın göstərilməsi zamanı xəstənin huşunun keyləşməsi, kəskin halsızlıq, zəiflik, hipotenziv (AT 70130, Nəbz dəqiqədə 138 sapvari) vəziyyət aşkar edilmiş, IV aggressiv infuziya başlanaraq klinikaya hospitalizasiya olunmuşdur.

\section{Anamnesis vita.}

14 il öncə (2000) oxşar simptomlarla Moskvanın uşaq xəstəxanalarının birində "Kəskin qaraciyər və böyrək çatışmazlığı” diaqnozu ilə tam sağalma ilə nəticələnən müalicə (qan məhsullarının köçürülməsi, hemodializ, habelə digər farmakoloji terapiya) almışdır.

Təkrarən 9 il il öncə (2005) xəstə yenidən oxşar şikayətlərlə və ağır kliniki vəziyyətdə Moskva xəstəxanasında "Hemolitik uremik sindrom. Kəskin böyrək və qaraciyər çatışmazlığı" qiaqnozu ilə yenidən tam sağalma ilə nəticələnən müalicə almışdır (plazmaferez; hemodializ 3 aya yaxış davam edib). Son 5 ildə isə xəstə hər hansı bir xəstəlik keçirməmiş, cərrahi əməliyyat olunmamış və heç bir dərman qəbul etməmişdir.

Xəstədə həmçinin əvvəllər oral və ya nazal xoralar, oynaq və ya plevritik ağrılar olmayıb. Fotosensitivlik qeyd edilmir.

\section{Ailə anamnezi.}

Ailə üzvləri və yaxın qohumlarında oxşar simptomları olan xəstəlik qeydə alınmayıb. Hər hansı genetik və ya irsi xəstəliklər, o cümlədən, hematoloji və/və ya onkoloji xəstəliklər olmayıb. Ailədə böyrək və ya qaraciyər xəstəliyi inkar edilir.

\section{Sosial vəziyyət.}

Xəstənin yaxınları tərəfindən verilən məlumata əsasən xəstə dörd gün öncə Rusiyanın Moksva şəhərindən Bakıya qonaq gəlmiş (birinci gəlişi deyil və xəstə əvvəllər də Bakıda yaşamışdır) və bu yaxınlarda heç bir xəstəlik keçirməmiş, soyuqdəymə və ya kəskin respirator xəstəlik, kəskin mədəbağırsaq xəstəliyi ilə bağlı heç bir şikayətləri və simptomları olmamışdır. Xəstənin ümumən çox aktiv olduğu, gündəlik idmanla məşğul olması vurğulanmışdır.

Siqaret çəkməyib və çəkmir. Alkoqoldan çox nadir istifadə edir. Cinsi yolla keçən xəstəlikləri olmayıb. Ali təhsil ocağında təhsilini davam etdirir.

\section{Sistem orqanlara baxış.}

- Baş-qulaq-burun-boğaz: üzündə qırmızı ləkələr peydə olmuş və sayı artmaqdadır. Boğazı ağrımır. Udqunma sərbəstdir. Burundan qanaxma və ya digər ifrazat yoxdur. Görməsi normaldır və dəyişməyib.

- Mədə-bağırsaq sistemi: qarında ağrı, ishal və qusma, ürək bulanma.

- Ürək-damar sistemi: ürək ağrısı yoxdur, ürək döyüntülərinin pozulmasını hiss etmir.

- Tənəffüs sistemi: norma daxilində.

- Otraflar: zəiflik.

- Sidik-cinsiyyət sistemi: sidiyə getmə pisləşib, miqdarı azalıb, sidik ifrazı zamanı yanğı hissi yoxdur.Sidiyin rəngi dəyişməyib.

- Ozələ-sümük sistemi: əzələ ağrıları yoxdur.

- Sinir sistemi: bayılma və ümumi zəiflik.

\section{Fiziki müayinə.}

Həyati göstəricilər: Hərarət - 36.4C, Nəbz - 120-130 vurğu/dəqiqə, SaO2 - 94\%, Arteriyal təzyiq - 80/60 mm c.s., Tənəffüs tezliyi - 18/dəqiqədə

- Baş-qulaq-burun-boğaz: üzündə qırmızı rəngdə səthi ekximozlar qeyd olunur və onlar birləşmir. Boğazında qızartı yoxdur, badamcıqlar ödemsizdir. Burunun selikli gişası hiperemik 
deyildir. Görmə sahələrində patologiya aşkar edilmir. Skleralar ikterikdir.

- Mədə-bağırsaq sistemi: qarın yumşaqdır, palpasiyada diffuz ağrı hissi vardır; qarından əlin çəkilməsi simptomu (periton qıcıqlanması) neqativdir, bağırsaq küyləri hipoaktivdir.

- Ürək-damar sistemi: S1S2 normal, küylər eşidilmir, taxikardiya qeyd edilir.

- Tәnəffüs sistemi: tənəffüs sərbəstdir, auskultasiyada xırıltılar eşidilmir. Təngənəfəslik yoxdur.

- Otraflar: ödem yoxdur; ətraflarda tüklənmə adidir, periferik damarlarda nəbz əllənir və normal dolğunluqludur.

- Dəri: üzündə ekximotik səpgilər vardır;

- Sidik-cinsiyyət sistemi: müayinə edilməyib.

- Әzələ-sümük sistemi: əzələlərdə tonus normaldır, əzələlərin inkişafı yaşa uyğundur; ətraflarda əzələlərin gücü $4 / 5$.

- Sinir sistemi: nevroloji defisit qeydə alınmır.

- Psixi vəziyyət: huşu keyləşmişdir; suallara cavablar gecikmiş olsa da, düzgündür; sayıqlama yoxdur.

\section{Diaqnostik müayinələr:}

Qarının USM: böyrəklər ödemlidir, ölçüləri böyümüşdür; obstruktiv uropatiya əlamətləri müəyyən edilmir.

\section{Differensial diaqnostika.}

\section{Sepsis/septik şok:}

Qeyd edildiyi kimi, xəstənin kliniki vəziyyəti tam sağlamlıq fonunda ani dəyişmişdir. Onun ilkin müayinəsi zamanı taxikardiya, hipotenziya olsa da, hipo- və ya hipertermiya, leykositoz və ya leykopeniya, və heç bir infeksiya mənbəyi aşkar edilməmişdir. Həmçinin, toplanmış anamnezdən məlum olmuşdur ki, xəstə bu yaxınlarda heç bir infeksion və ya digər xəstəlik keçirməmişdir. Xəstənin ilkin müayinəsi zamanı bütün müalicəvi tədbirlərin başlanmasından əvvəl götürülmüş qan və sidiyin mikrobioloji (sterilliyə yoxlanılması) əkilməsi də mənfi nəticələr vermişdir. Buna görə də sepsis və septik şok istisna edilmişdir.

\section{Hemolitik-uremik sindrom-Trombotik trombositopenik purpura:}

yuxarıda qeyd edildiyi kimi, HUS/TTP hallarında xəstələrdə simptomların pentadası (trombositopeniya, mikroangiopatik hemolitik anemiya, hərarət, qanda kreatininin artması və nevroloji simptomlar) nadir hallarda müşahidə edilir. TTP-nin atipik hallarının tanınması və müalicəsinə start verilməsi xəstələrin sağ qalmasına təsir edən mühüm faktordur. Hazırda kliniki təcrübədə TTP-
HUS triadası ilə (yüksək LDH, trombositopeniya və periferik qanın yaxmasında şistositlər) daxil olan xəstələrdə təcili plazmaferezə başlanılır. Bunu, habelə anamnez və laborator göstəriciləri nəzərə alaraq, xəstəyə TTP-HUS diaqnozu qoyulmuş və empirik olaraq plazmaferez təcili olaraq başlanmışdır. Sonradan bu taktikanın düzgün olduğu təsdiqini tapmışdır.

\section{Disseminə olunmuş damardaxili laxtalanma (defibrinasiya):}

DDL ilə TTP-HUS-un differensial diaqnostikası həmişə çətinliklərlə bağlıdır. Bu da onların kliniki əlamətləri və bir çox laborator göstəricilərinin oxşar olması ilə bağlıdır. Lakin, anamnez və spesifik laborator testlərlə bu iki patologiyanı differensiasiya etmək mümkündür. Düzdür, DDL-in diaqnostikası üçün hansısa konkret laborator testin nəticəsi ayrılıqda istifadə edilə bilməz. Ümumiyyətlə, DDL-in əsasən sepsis və septik şok, ginekoloji əməliyyatlar və ya saxlanmış hamiləliklə bağlı olduğunu nəzərə alaraq və təsvir edilən xəstədə bunlardan heç birinin olmadığını əsas götürərək, DDL diaqnozu ikinci plana keçmişdir. Düzdür, TTP-HUS-dan fərqli olaraq DDL-də damardaxili koaqulyasiyanın baş verməsi, damardaxili fibrin tromblarının (TTP-HUS-da bu tromblar trombositlərdən ibarət olur) əmələ gəlməsi və koaqulyasiya faktorlarının tükənməsi müəyyən edilir. Və bu xəstədə PT və aPTT-nın uzanması, ddimerin yüksək olması, fibrinogenin səviyyəsinin aşağı düşməsi DDL-ə dəlalət etsə də, onun baş verməsini şərtləndirən səbəb müəyyən edilməmişdir. Təsvir edilmiş xəstədə koaqulopatiyanın inkişafı isə fikrimizcə qaraciyər və digər daxili orqanlarda diffuz toxuma işemiyasının inkişafı ilə bağlı olmuşdur.

\section{Komplement mənşəli atipik hemolitik uremik sindrom.}

Bəzi xəstələrdə mikroangiopatik hemolitik anemiya, trombositopeniya və kəskin böyrək çatışmazlığı damarların endotelial səthində alternativ komplement yolunun uyğunsuz aktivasiyası nəticəsində inkişaf edir. Komplement faktorlarını kodlaşdıran genlərin mutasiyası və ya komplement faktorlarına qarşı anticismlərin formalaşması bu cür atipik HUS hallarının əmələ gəlməsinə səbəb olur. Komplement mənşəli atipik HUS diaqnozu əsasən uşaqlıqda qoyulur. $\mathrm{Bu}$ xəstədə $\mathrm{C} 3$ və $\mathrm{C} 4$ komplement faktorlarının norma daxilində olması atipik HUS-u istisna etməyə imkan vermişdir.

\section{Sistem xəstəliklər/autoimmun xəstəlik səbəbindən inkişaf edən TTP.}

Trombositopeniya, mikroangiopatik hemolitik anemiya və böyrək çatışmazlığı bir sıra sistem 
xəstəliklərdə, o cümlədən, sistemli vaskulit və bədxassəli hipertoniya hallarında müşahidə edilə bilər. Vaskulit və ya digər birleşdirici toxuma xəstəliklərində (məs., qırmızı qurd eşənəyi -SLE, skleroderma, revmatoid artrit) TTP-HUS-a dəlalət edən simptomlarla yanaşı sistem xəstəliyin digər əlamətləri, məs., səpgi, artralgiyalar, periferik və mərkəzi sinir sisteminin pozuntuları (mononevrit multipleks, mərkəzi sinir sisteminin lupusu) da mövcud olur. $\mathrm{Bu}$ xəstədə sistem xəstəliyin olmaması, ANA-nın norma daxilində olması, habelə kardiolipin İgG və İgM-in norma daxilində olması sistemli vaskulit və digər sistem xəstəliyinin istisna edilməsinə imkan vermişdir.

\section{Xəstəliyin klinik gedişatı və müalicə.}

Xəstənin təcili tibbi yardım xəstəxanasına gətirildikdə (saat 01:10-da) həyati göstəriciləri təkrar yoxlanılmış və AT-in $80 / 50 \mathrm{~mm}$ c.s. və nəbzin dəqiqədə 110 vurğu olduğu müəyyən edilmişdir. Təcili şəkildə periferik venalara iri diametrli iki damardaxili kateter qoyulmuş, analiz üçün qan nümunələri götürülmüş, $\mathrm{o}$ cümlədən, qanın sterilliyinin təyini üçün iki müxtəlif lokalizasiyadan mikrobioloji əkmə üçün venoz qan əldə edilmişdir. Dərhal $500 \mathrm{ml} 0.9 \%-\mathrm{I}$ $\mathrm{NaCl}$ məhlulu ilə sürətli infuziya başlanmışdır. Bununla yanaşı sidik kisəsi daxilinə kateter qoyulmuş və sidik analizi və sidik çöküntüsünün müayinəsi və sidiyik əkilməsi üçün sidik nümunəsi əldə edilmişdir. Xəstəyə ilk iki saat ərzində $2.5 \mathrm{~L} 0.9 \%$-lı $\mathrm{NaCl}$ və $500 \mathrm{ml} 5 \%$-lı qlükoza məhlulunun köçürülməsinə baxmayaraq, sidik ifrazı çox minimal olmuş, qan təzyiqi isə artmamışdır. Hemodinamik qeyri-stabilliyi və böyrəklərin çatışmazlığını nəzərə alaraq, dofamin IV məhlulunun infuziyası başlanılmış və sistolik AT-in $>100 \mathrm{~mm}$ c.s. və OAT (orta arteriyal təzyiqin) >65 $\mathrm{mm}$ c.s.-dan yuxarı saxlamaq üçün dofaminin dozası müvafiq olaraq tənzimlənmişdir. Maye infuziyası və dofaminin infuziyası nəticəsində xəstənin hemodinamikası stabilləşmiş, huşu xeyli yaxşılaşmışdır. Lakin, sidik ifrazı çox az artmış və növbəti dörd saat ərzində xəstə cəmi $50 \mathrm{ml}$ sidik ifraz etmiş və onun rəngi tünd qara olmuşdur.

Qan və sidiyin analizləri kəskin böyrək və kəskin qaraciyər çatışmazlıqlarının inkişaf etdiyini (Kreatinin $115 \mathrm{mkmol} / \mathrm{L}$, ümumi bilirubin 142.5 $\mathrm{mkmol} / \mathrm{L}$, düz bilirubin $55.8 \mathrm{mkmol} / \mathrm{L}$, qeyri-düz biliribun $86.6 \mathrm{mkmol} / \mathrm{L}$, ALAT $129 \mathrm{vahid} / \mathrm{L}$, AST 291 vahid/L), habelə ağır koaqulopatiyanın olduğunu (PT>40.8 saniyə, INR 2.7, fibrinogen $119 \mathrm{mq} / \mathrm{dL}$, anti-trombin $60.3 \%$, protrombin index $36.3 \%$, aPTT 51.4 saniyə, D-dimer $10.5 \mathrm{uq} / \mathrm{ml}$, prokalsitonin 13 $\mathrm{nq} / \mathrm{ml}$, CRP 38.5 və ANA 13.5) göstərmişdir. Diqqəti çəkən məqam qanda $\mathrm{Hb} / \mathrm{Hct}$ və leykositlərin norma daxilində olması ( $\mathrm{Hb} 128$ q/L, Hct 35\%, leykositlər $\left.5.35^{*} 109 / \mathrm{L}\right)$, hərarətin olmaması, lakin trombositlərin 109x109/L olması olmuşdur. Lakin, xəstədə təkrar ishal və qusma səbəbindən hipovolemiyanın olduğunu nəzərə alaraq, qeyd edilmiş laborator göstəricilər hemokonsentrasiya ila əlaqələndirilmişdir. İki saat sonra götürülən qan analizində trombositlərin sayı artıq 80x109/L düşmüşdür. Qanın periferik yaxmasında qırmızı qan hüceyrələri normositik olmuş, çoxlu sayda şistositlər müəyyən edilmişdir və Kumbs testi də neqativ olmuşdur.

HUS-TTP diaqnozu nəzərdən keçirildiyi üçün xəstəyə $16 \mathrm{mq}$ deksametazon iv vurulmuşdur. Bunlarla yanaşı xəstəliyin proqressiv inkişafını və trombositopeniyanın proqressivləşməsini, habelə ağır koaqulopatiyanın olduğunu nəzərə alaraq, təcili olaraq təzə dondurulmuş plazma sifariş verilmişdir.

Xəstədən saat 07:10-da götürülmüş təkrar qan analizində koaqulopatiyanın, trombositopeniyanın, anemiyanın və böyrək və qaraciyər çatışmazlıqlarının daha da proqressivləşməsi qeydə alınmışdır (Kreatinin $130 \mathrm{mkmol} / \mathrm{L}$, INR 4.6, aPTT 208 saniyə, LDH 2462 vahid/L, Hb 100 q/L, Hct $26.7 \%$, Trombositlər $82 \times 109 / \mathrm{L})$. Bu fonda xəstədə təcili olaraq plazmaferezə start verilmişdir. Bununla yanaşı böyrək çatışmazlığı, artıq maye yüklənməsi və ağır dərəcəli oliquriyanın inkişaf səbəbindən hemodializin aparılması da təyin edilmişdir. İlk 6 saat ərzində aparılan tədbirlər nəticəsində xəstənin hemodinamikası stabilləşdirilmiş və vazopressorun (dofamin məhlulu) infuziyası dayandırılmışdır.

Hospitalizasiyanın ikinci günü xəstədə oliquriya davam etmiş, təkrar analizlərdə trombositlərin sayı 56x109/L-ya düşmüş, leykositlərin sayı isə 30.04×109/L yüksəlmişdir (steroid mənşəli). Mikroangiopatiyanın yaxşılaşmasını müəyyən etmək üçün LDH səviyyəsi monitorinq edilmişdir. Aparılan müalicəvi tədbirlərin fonunda artıq hospitalizasiyasının dördüncü günü LDH səviyyəsi enməyə başlamış və 718 vahid/L olmuşdur.

Dəstəkləyici infuzion və antibiotik terapiyası ilə yanaşı aparılan gündəlik plazmaferez və davam etdirilən gündəlik IV prednizon sayəsində xəstənin ümumi vəziyyəti və laborator göstəriciləri hospitalizasiyanın artıq üçüncü günü yaxşılaşmağa meyillik göstərmiş, qaraciyərin funksional panelində yaxşılaşma qeyd edilmişdir (ümumi bilirubin, ALT, AST xeyli aşağı düşmüşdür). Eyni zamanda ilk gün müşahidə edilən ağır dərəcəli koaqulopatiya da yaxşılaşmışdır və artıq ikinci gün INR 2.0, aPTT 37.3 saniyə olmuş, Fibrinogen $269 \mathrm{mq} / \mathrm{dL}$, LDH isə 1604 vahid/L-ə enmişdir. Lakin, trombositlərin sayı enməyə davam etmiş və hospitalizasiyanın ikinci günü 70x109/L, dördüncü günü 60x109/L olmuşdur. Bununla yanaşı $\mathrm{Hb} 80 \mathrm{q} / \mathrm{L}$ və Hct isə $22 \%$ olmuş və хәstəyə hospitalizasiya müddətində ümumilikdə 
dörd paket Eritrositar kütlə transfuziya edilmişdir. Həmçinin, böyrək çatışmazlığı ağırlaşmış, xəstədə anuriya inkişaf etmiş və hospitalizasiyanın beşinci günü xəstənin kreatinini $434 \mathrm{mkmol} / \mathrm{L}$, qanda sidik cövhəri isə $23.4 \mathrm{mmol} / \mathrm{L}$ olmuşdur.

Hospitalizasiyanın altıncı günündən başlayaraq davam etdirilən iV steroid (prednizon) və plazmaferez və gündəlik hemodializ sayəsində trombositlərin sayı artmağa başlamış və hospitalizasiyanın yeddinci günü trombositlərin sayı 127x109/L olmuşdur.

Kliniki olaraq, xəstənin vəziyyəti yaxşılaşmış, sidik ifrazının həcmi proqressiv olaraq növbəti günlər ərzində artmağa başlamışdır. Qaraciyərin funksional paneli normallaşmış, koaqulopatiya korreksiya olunmuş və kreatinin əhəmiyyətli dərəcədə enmişdir. Bu göstəriciləri və kliniki vəziyyətin, o cümlədən, sidik ifrazının normallaşdığını nəzərə alaraq, habelə trombositlərin sayının hospitalizasiyanın səkkizinci günü artıq 207x109/L olduğunu əsas götürərək plazmaferezlə hemodializ prosedurları dayandırımışdır. Lakin, prednizonla terapiya davam etdirilmişdir.

Xəstənin təxminən 20 gün davam edən hospitalizasiyası ərzində 8 plazmaferez sessiyası keçirilmiş, bununla yanaşı 77 paket FFP (təzə dondurulmuş plazma) transfuziya olunmuş və 12 seans hemodializ aparılmışdır. Qeyd edilməlidir ki, sepsis və disseminə olunmuş damardaxili laxtalanmaya şübhənin olmasına baxmayaraq, xəstədən götürülmüş qan və sidiyin əkilməsi mənfi nəticələr vermişdir.

\section{MÜZAKİRO.}

HUS/TTP hallarında xəstələrdə simptomların pentadası (trombositopeniya, mikroangiopatik hemolitik anemiya, hərarət, qanda kreatininin artması və nevroloji simptomlar) nadir hallarda müşahidə edildiyi üçün, TTP-nin atipik hallarının tanınması və müalicəsinə start verilməsi xəstələrin sağ qalmasına təsir edən mühüm faktordur. Hazırda kliniki təcrübədə TTP-HUS triadası ilə (yüksək LDH, trombositopeniya və periferik qanın yaxmasında şistositlər) daxil olan xəstələrdə təcili plazmaferezə başlanılır.

Plazma mübadiləsinin tətbiqindən əvvəl TTPIHUS xəstələri arasında mortalite $>90 \%$-dən də çox olub, hazırda isə plazmaferezin tətbiqi sayəsində mortalite 20\%-dən azdır. Plazma mübadiləsi ilə plazmada dövr edən ADAMTS13-ə qarşı autoanticismlərin və VWF-un böyük multimer formalarının təmizlənməsi aparılır. Bununla yanaşı xəstənin plazmasında çatışmayan və ya nisbi çatışmazlığı yaranmış vWF-CP plazma proteazasının bərpası da təmin edilir.
Bu xəstədə TTPIHUS diaqnozunun erkən nəzərdən keçirilməsi və empirik diaqnozun qoyulmasından sonra 6 saat ərzində plazmaferezin başlanması nəticəsində xəstənin kliniki vəziyyəti yaxşılaşmış və 20 gündən sonra xəstə evə yazılmışdır. TTP-HUS tibbii təxirəsalınmaz haldır və plazmaferez erkən tətbiq edilmədikdə xəstənin ölümü ilə nəticələnir. Bu xəstələrdə trombositopeniaynın korreksiyası üçün trombositar kütlənin transfuziyası tövsiyə edilmir, çünki trombositlərin transfuziyası damardaxili trombozu daha da kəskinləşdirir və kliniki nəticələri daha da pisləşdirir. Ümumiyyətlə, TTP-HUS diaqnozu olan xəstələrdə həyata təhlükə törədən qanaxma olmadıqda trombositar kütlənin transfuziyası məsləhət görülmür.

\section{BIBLIOQRAFIYA.}

1. Keir LS. Shiga toxin associated hemolytic uremic syndrome. Hematol Oncol Clin North Am. 2015 Jun. 29 (3):525-39.

2. Conway EM. HUS and the case for complement. Blood. 2015 Oct 29. 126 (18):2085-90.

3. Siegler RL. Management of hemolytic-uremic syndrome. J Pediatr. 1988 Jun. 112(6):1014-20.

4. Siegler R, Oakes R. Hemolytic uremic syndrome; pathogenesis, treatment, and outcome. Curr Opin Pediatr. 2005 Apr. 17(2):200-4.

5. Furlan M, Robles R, Galbusera $M$, et al. von Willebrand factor-cleaving protease in thrombotic thrombocytopenic purpura and the hemolyticuremic syndrome. N Engl J Med. 1998 Nov 26. 339(22):1578-84.

6. Tsai HM, Lian EC. Antibodies to von Willebrand factor-cleaving protease in acute thrombotic thrombocytopenic purpura. N Engl J Med. 1998 Nov 26. 339(22):1585-94.

7. George JN. ADAMTS13, thrombotic thrombocytopenic purpura, and hemolytic uremic syndrome. Curr Hematol Rep. 2005 May. 4(3):167-9.

8. Haspel RL, Jarolím P. The "cutting" edge: von Willebrand factor-cleaving protease activity in thrombotic microangiopathies. Transfus Apher Sci. 2005 Apr. 32(2):177-84.

9. Blackall DP, Marques MB. Hemolytic uremic syndrome revisited: Shiga toxin, factor $\mathrm{H}$, and fibrin generation. Am J Clin Pathol. 2004 Jun. 121 suppl:S81-8.

10. Tarr PI, Gordon CA, Chandler WL. Shigatoxin-producing Escherichia coli and haemolytic uraemic syndrome. Lancet. 2005 Mar 19-25. 365(9464):1073-86.

11. Frank C, Werber D, Cramer JP, et al. Epidemic profile of Shiga-toxin-producing 
Escherichia coli O104:H4 outbreak in Germany.

N Engl J Med. 2011 Nov 10. 365(19):1771-80.

12. Saad AF, Roman J, Wyble A, Pacheco LD. Pregnancy-Associated Atypical HemolyticUremic Syndrome. AJP Rep. 2016 Mar. 6 (1):e125-8.

13. Caprioli J, Bettinaglio P, Zipfel PF, et al. The molecular basis of familial hemolytic uremic syndrome: mutation analysis of factor $\mathrm{H}$ gene reveals a hot spot in short consensus repeat 20 . J Am Soc Nephrol. 2001 Feb. 12(2):297-307.

14. Fremeaux-Bacchi V, Kemp EJ, Goodship JA, Dragon-Durey MA, Strain L, Loirat C, et al. The development of atypical haemolytic-uraemic syndrome is influenced by susceptibility factors in factor $\mathrm{H}$ and membrane cofactor protein: evidence from two independent cohorts. J Med Genet. 2005 Nov. 42(11):852-6.

15. Edey MM, Mead PA, Saunders RE, et al. Association of a factor $\mathrm{H}$ mutation with hemolytic uremic syndrome following a diarrheal illness. Am J Kidney Dis. 2008 Mar. 51(3):487-90.

16. Lapeyraque AL, Wagner $\mathrm{E}$, Phan $\mathrm{V}$, et al. Efficacy of plasma therapy in atypical hemolytic uremic syndrome with complement factor $\mathrm{H}$ mutations. Pediatr Nephrol. 2008 Aug. 23(8):1363-6.

17. Kojouri K, Vesely SK, George JN. Quinineassociated thrombotic thrombocytopenic purpura-hemolytic uremic syndrome: frequency, clinical features, and long-term outcomes. Ann Intern Med. 2001 Dec 18. 135(12):1047-51.

18. Adams DA, Jajosky RA, Ajani U, Kriseman $J$, Sharp $P$, Onwen $D H$, et al. Summary of notifiable diseases--United States, 2012. MMWR Morb Mortal Wkly Rep. 2014 Sep 19. 61(53):1121.

19. Schuppner R, Maehlmann J, Dirks $M$, Worthmann $H$, Tryc $A B$, Sandorski $K$, et al. Neurological Sequelae in Adults After $E$ coli O104: H4 Infection-Induced Hemolytic-Uremic Syndrome. Medicine (Baltimore). 2016 Feb. 95 (6): $\mathrm{e} 2337$.

20. Santos AH Jr, Casey MJ, Wen X, Zendejas I, Faldu C, Rehman S, et al. Outcome of kidney transplants for adults with hemolytic uremic syndrome in the U.S.: a ten-year database analysis. Ann Transplant. 2014 Jul 21. 19:35361.

21. Al-Akash, S.I. , Almond, P.S. , Savell, Jr, V.H. , Gharaybeh, S.I. \& Hogue, C. (2011) Eculizumab induces long-term remission in recurrent post-transplant HUS associated with C3 gene mutation. Pediatric Nephrology (Berlin, Germany), 26, 613-619.
22. Allford, S.L. , Harrison, P. , Lawrie, A.S. , Liesner, R. , MacKie, I.J. \& Machin, S.J. (2000) Von Willebrand factor-cleaving protease activity in congenital thrombotic thrombocytopenic purpura. British Journal of Haematology, 111, 1215-1222.

23. Allford, S.L. , Hunt, B.J., Rose, P. \& Machin, S.J. (2003) Guidelines on the diagnosis and management of the thrombotic microangiopathic haemolytic anaemias. British Journal of Haematology, 120, 556-573.

24. Ambrose, A. , Welham, R.T. \& Cefalo, R.C. (1985) Thrombotic thrombocytopenic purpura in early pregnancy. Obstetrics and Gynecology, 66, 267-272.

25. Ariceta, G. , Besbas, N. , Johnson, S. , Karpman, D. , Landau, D. , Licht, C. , Loirat, C. , Pecoraro, C. , Taylor, C.M. , Van de Kar, N. , Vandewalle, J. \& Zimmerhackl, L.B. (2009) Guideline for the investigation and initial therapy of diarrhea-negative hemolytic uremic syndrome. Pediatric Nephrology (Berlin, Germany), 24, 687696.

26. Balduini, C.L. , Gugliotta, L. , Luppi, M. , Laurenti, L. , Klersy, C. , Pieresca, C. , Quintini, G. , luliano, F. , Re, R., Spedini, P., Vianelli, N. , Zaccaria, A., Pogliani, E.M. , Musso, R., Bobbio, P.E. , Quarta, G. , Galieni, P. , Fragasso, A. , Casella, G. , Noris, P. \& Ascari, E. (2010) High versus standard dose methylprednisolone in the acute phase of idiopathic thrombotic thrombocytopenic purpura: a randomized study. Annals of Hematology, 89, 591-596.

27. Bandarenko, N. \& Brecher, M.E. (1998) United States Thrombotic Thrombocytopenic Purpura Apheresis Study Group (US TTP ASG): multicenter survey and retrospective analysis of current efficacy of therapeutic plasma exchange. Journal of Clinical Apheresis, 13, 133-141.

28. Bayik, M.M. , Akoglu, T. , Tuglular, T.F. , Akoglu, E. , Tezal, M. , Ulutin, O. \& Lawrence, R. (1993) Treatment of thrombotic thrombocytopenic purpura with defibrotid. American Journal of Hematology, 43, 74-75.

29. Bianchi, V. , Robles, R. , Alberio, L. , Furlan, M. \& Lammle, B. (2002) Von Willebrand factorcleaving protease (ADAMTS13) in thrombocytopenic disorders: a severely deficient activity is specific for thrombotic thrombocytopenic purpura. Blood, 100, 710-713.

30. Bobbio-Pallavicini, E. , Gugliotta, L. , Centurioni, R. , Porta, C. , Vianelli, N. , Billio, A. , Tacconi, F. \& Ascari, E. (1997) Antiplatelet agents in thrombotic thrombocytopenic purpura (TTP). Results of a randomized multicenter trial 
by the Italian Cooperative Group for TTP. Haematologica, 82, 429-435.

31. Bohm, M. , Betz, C. , Miesbach, W. , Krause, M. , von Auer, C. , Geiger, H. \& Scharrer, I. (2005) The course of ADAMTS-13 activity and inhibitor titre in the treatment of thrombotic thrombocytopenic purpura with plasma exchange and vincristine. British Journal of Haematology, 129, 644-652.

32. Bresin, E. , Gastoldi, S., Daina, E., Belotti, D. , Pogliani, E., Perseghin, P. , Scalzulli, P.R., Paolini, R. , Marceno, R. , Remuzzi, G. \& Galbusera, M. (2009) Rituximab as pre-emptive treatment in patients with thrombotic thrombocytopenic purpura and evidence of antiADAMTS13 autoantibodies. Thrombosis and Haemostasis, 101, 233-238.

33. Brunskill, S.J. , Tusold, A. , Benjamin, S. , Stanworth, S.J. \& Murphy, M.F. (2007) A systematic review of randomized controlled trials for plasma exchange in the treatment of thrombotic thrombocytopenic purpura. Transfusion Medicine (Oxford, England), 17, 1735.

34. Cataland, S.R. , Jin, M. , Ferketich, A.K. , Kennedy, M.S. , Kraut, E.H. , George, J.N. \& $\mathrm{Wu}$, H.M. (2007a) An evaluation of cyclosporin and corticosteroids individually as adjuncts to plasma exchange in the treatment of thrombotic thrombocytopenic purpura. British Journal of Haematology, 136, 146-149. 